\title{
Effect of Consciousness Energy Healing Treatment on the Physicochemical and Thermal Properties of Selenium
}

\author{
Alice Branton ${ }^{1}$, Mahendra Kumar Trivedi', Dahryn Trivedi ${ }^{1}$, Gopal Nayak ${ }^{1}$, Snehasis Jana ${ }^{2 *}$ \\ ${ }^{1}$ Trivedi Global, Inc., Henderson, USA \\ ${ }^{2}$ Trivedi Science Research Laboratory Pvt. Ltd., Bhopal, India
}

*Corresponding author: Snehasis Jana, Trivedi Science Research Laboratory Pvt. Ltd.,Bhopal, India. Tel: +91-022-25811234; Email: publication@trivedieffect.com

\begin{abstract}
Selenium is an essential micronutrient which is useful for various biological functions in the body, as well as prevention and treatment of selenium deficiency-related diseases. The aim of this study was to evaluate the physicochemical and thermal properties of the Trivedi Effect ${ }^{\circledR}$-Consciousness Energy Healing Treatedselenium using the modern analytical technique. The test sample was divided into two parts viz. control and treated sample. The control sample did not receive Biofield Energy Treatment; whereas the treated sample received the Biofield Treatment remotely by a renowned Biofield Energy Healer, Alice Branton. The PXRD peak intensities and crystallite sizes were significantly altered ranging from -21.59 to $412.20 \%$ and $-6.90 \%$ to $40.68 \%$ respectively; however, the average crystallite size was significantly increased by $5.44 \%$ in the treated sample compared with the control sample. The particle size values were altered by $-4.54 \%\left(\mathrm{~d}_{10}\right), 0.92 \%\left(\mathrm{~d}_{50}\right), 1.18 \%\left(\mathrm{~d}_{90}\right)$, and $0.66 \%\{\mathrm{D}(4,3)\}$, respectively, thus the specific surface area was increased by $2.48 \%$ in the treated sample compared to the control sample. The melting point and latent heat of fusion of the treated selenium were increased by $0.27 \%$ and $5.94 \%$, respectively compared with the control sample. The residue amount was increased by $3.83 \%$ in the treated selenium compared with the control sample. The maximum thermal degradation temperature of the treated sample was significantly increased by $14.94 \%$ compared with the control sample. The Biofield Energy Treatment might have generated a new polymorphic form of selenium which would be more efficacious against diabetes, cancer, cardiovascular disease, viral diseases, male infertility, stress, aging, muscle disorders, neurological disorders, degenerative ailments, etc.
\end{abstract}

Keywords: Selenium, Consciousness Energy Healing Treatment, The Trivedi Effect ${ }^{\circledR}$, Complementary and Alternative Medicine, PXRD, Particle size, DSC, TGA/DTG

\section{Introduction}

Selenium (Se) is one of the important minerals, required as an essential micronutrient by the human and animals for various biological functions such as healthy metabolism and inhibition of the toxic effect of heavy metals ${ }^{[1]}$. Selenium comes from the diet like meat, fish, nuts, cereals, mushrooms, and mineral supplements/ multi-vitamins ${ }^{[1,2]}$. Selenium is present in the active site of enzymes (selenium enzymes) like glutathione peroxidase, ribonucleotide reductase, etc. and also in around 30 proteins as selenocysteine (selenoprotein) ${ }^{[3]}$. It acts as a potent antioxidant, protects from oxidative damage and infection, protects nerve, plays critical roles in reproduction, thyroid hormone metabolism, and DNA synthesis ${ }^{[1,4,5]}$. Besides, the inequity level of selenium in the body is found to be involved in the pathophysiology of several diseases, such as type-2 diabetes, cancer, cardiovascular disease, viral diseases, male infertility, muscle disorders, neurological disorders, degenerative ailments, etc. ${ }^{[6-8]}$. Therefore, the supplements containing selenium are essential for those populations that may not easily consume it through diet due to their poor selenium containing foods or genetic variations ${ }^{[9]}$. Since the low level of Se in the
Received date: September 24, 2018 Accepted Date: October 19, 2018 Published Date: October 24, 2018

Citation: Branton, A., et al. Effect of Consciousness Energy Healing Treatment on the Physicochemical and Thermal Properties of Selenium. (2018) Int J Food Nutr Sci 5(1): 74- 80 .

Copyright: (C) 2018 Branton, A. This is an Open access article distributed under the terms of Creative Commons Attribution 4.0 International License. 
body may create concern for deficiency diseases; it is recommended as a daily supplement in several countries. However, the excess intake of Se may cause adverse health effects ${ }^{[10]}$.

The absorption rate of $\mathrm{Se}$ in selenite form is more than 80 percent in the body. The physicochemical properties of a pharmaceutical or nutraceutical play a crucial role in its dissolution, absorption and bioavailability profile ${ }^{[11]}$. Therefore, the researchers pay their devotion for improving these parameters of the pharmaceuticals or nutraceuticals. It had been observed that the Biofield Energy Healing Treatment (the Trivedi Effect ${ }^{\mathbb{R}}$ ) has the considerable impact on various properties such as particle size, surface area, and other chemical and thermal behaviour of pharmaceutical/nutraceutical ${ }^{[12-15]}$. The Trivedi Effect ${ }^{\mathbb{B}}$ is natural and only scientifically proven phenomenon in which a person can harness this inherently intelligent energy and transmit it anywhere on the planet through the possible mediation of neutrinos $^{[12]}$. Every living organism possesses this kind of unique energy surrounding the body known as "Biofield", which is an infinite, para-dimensional electromagnetic field. Biofield (Putative Energy Fields) based Energy Healing Therapies have been reported to have significant outcomes against various disease conditions $^{[16]}$. The National Institutes of Health/National Center for Complementary and Alternative Medicine (NIH/NCCAM) recommend and included the Energy therapy under the Complementary and Alternative Medicine (CAM) category along with Ayurvedic medicine, traditional Chinese herbs and medicines, homeopathy, acupuncture, acupressure, yoga, healing touch, Reiki, hypnotherapy, Tai Chi, Qi Gong, cranial sacral therapy, etc. Most of the U.S. people have accepted the CAM for their health and wellness ${ }^{[17,18]}$. The Trivedi Effect ${ }^{\mathbb{B}}$-Consciousness Energy Healing Treatment has been widely reported with astounding capability toalter the characteristic properties of the several non-living materials and living object(s), i.e. metals and ceramic ${ }^{[19,20]}$, organic compounds ${ }^{[21-23]}$, nutraceuticals/pharmaceuticals ${ }^{[13-15,24,25]}$ and crops ${ }^{[26,27]}$. The Consciousness Energy Healing Treatment has also enhanced the bioavailability of pharmaceutical/nutraceutical compounds ${ }^{[28-30]}$. Thus, this study was designed to evaluate the impact of the Trivedi Effect ${ }^{\circledR}$ on the physicochemical and thermal properties of selenium using powder X-ray diffraction (PXRD), particle size analysis (PSA), thermogravimetric analysis (TGA)/Differential thermogravimetric analysis (DTG), and differential scanning calorimetry (DSC).

\section{Materials and Methods}

\section{Chemicals and Reagents}

The selenium was purchased from Sigma Aldrich, USA. Remaining chemicals used during the experiments were of analytical grade available in India.

\section{Consciousness Energy Healing Treatment Strategies}

The selenium was the test sample divided into two parts. One part of selenium was considered as a control sample (no Biofield Energy Treatment was provided). Consequently, the second part of selenium was treated with the Trivedi Effect ${ }^{\mathbb{}}$-Consciousness Energy Healing Treatment remotely under standard laboratory conditions for 3 minutes and known as a Biofield Energy Treated selenium sample. This treatment was provided through the healer's unique energy transmission process by the renowned healer, Alice Branton, USA, to the test sample. Further, the control sample was treated with a "sham" healer. The "sham" healer did not aware about the Biofield Energy Treatment. After the treatment, the treated and untreated samples were kept in sealed conditions and characterized using PXRD, PSA, DSC, and TGA techniques.

\section{Characterization}

\section{Powder X-ray diffraction (PXRD) analysis}

The PXRD analysis of selenium was performed with the help of Rigaku MiniFlex-II Desktop X-ray diffractometer (Japan) ${ }^{[31,32]}$. The average size of individual crystallites was calculated from XRD data using the Scherrer's formula (1)

$\mathrm{G}=\mathrm{k} \lambda / \beta \cos \theta$

Where $\mathrm{k}$ is the equipment constant $(0.94), \mathrm{G}$ is the crystallite size in $\mathrm{nm}, \beta$ is the full-width at half maximum (FWHM), $\lambda$ is the radiation wavelength $(0.154056 \mathrm{~nm}$ for $\mathrm{K} \alpha 1$ emission $)$, and $\theta$ is the Bragg angle ${ }^{[33]}$.

The $\%$ change in crystallite size $(\mathrm{G})$ of seleniumwas calculated using the following equation 2 :

$\%$ change in crystallite size $=\left\{\left[\mathrm{G}_{\text {Treated }}-\mathrm{G}_{\text {Control }}\right] / \mathrm{G}_{\text {Control }}\right\} \times 100(2)$

Where $\mathrm{G}_{\text {Control }}$ and $\mathrm{G}_{\text {Treated }}$ are the crystallite size of the control andthe Biofield Energy Treated samples respectively.

\section{Particle size analysis(PSA)}

The particle size analysis of seleniumwas conducted on Malvern Mastersizer 2000, the UK with a detection range between 0.01 $\mu \mathrm{m}$ to $3000 \mu \mathrm{m}$ using wet method ${ }^{[34,35]}$. The calculations were done by using software Mastersizer Ver. 5.54.

The percent change in particle size (d) for seleniumat below $10 \%$ level $\left(\mathrm{d}_{10}\right), 50 \%$ level $\left(\mathrm{d}_{50}\right), 90 \%$ level $\left(\mathrm{d}_{90}\right)$, and $\mathrm{D}(4,3)$ was calculated using the following equation 3 :

$\%$ change in particle size $=\left\{\left[\mathrm{d}_{\text {Treated }}-\mathrm{d}_{\text {Control }}\right] / \mathrm{d}_{\text {Control }}\right\} \times 100$

Where $\mathrm{d}_{\text {Control }}$ and $\mathrm{d}_{\text {Treated }}$ are the particle size $(\mu \mathrm{m})$ at below $10 \%$ level $\left(\mathrm{d}_{10}\right), 50 \%$ level $\left(\mathrm{d}_{50}\right)$, and $90 \%$ level $\left(\mathrm{d}_{90}\right)$ of the control and the Biofield Energy Treated samples, respectively.

The percent change in surface area $(\mathrm{S})$ was calculated using the following equation 4 :

$\%$ change in surface area $=\left\{\left[\mathrm{S}_{\text {Treated }}-\mathrm{S}_{\text {Control }}\right] / \mathrm{S}_{\text {Control }}\right\} \times 100$

Where $\mathrm{S}_{\text {Control }}$ and $\mathrm{S}_{\text {Treated }}$ are the surface area of the control and the Biofield Energy Treated selenium respectively.

\section{Differential scanning calorimetry (DSC)}

The DSC analysis of selenium was performed with the help of DSC Q200, TA instruments. A sample of $\sim 1-5 \mathrm{mg}$ was loaded into the aluminium sample pan at a heating rate of $10{ }^{\circ} \mathrm{C} / \mathrm{min}$ from $30{ }^{\circ} \mathrm{C}$ to $350{ }^{\circ} \mathrm{C}{ }^{[34,35]}$. The $\%$ change in melting point $(\mathrm{T})$ was calculated using the following equation 5 : 
Citation: Branton, A., et al. Effect of Consciousness Energy Healing Treatment on the Physicochemical and Thermal Properties of Selenium. (2018) Int J Food Nutr Sci 5(1): 74- 80.

$\%$ change in melting point $=\left\{\left[\mathrm{T}_{\text {Treated }}-\mathrm{T}_{\text {Control }}\right] / \mathrm{T}_{\text {Control }}\right\} \times 100$

Where $\mathrm{T}_{\text {Control }}$ and $\mathrm{T}_{\text {Treated }}$ is the melting point of the control and treated samples respectively

The $\%$ change in the latent heat of fusion $(\Delta \mathrm{H})$ was calculated using the following equation 6 :

$\%$ change in latent heat of fusion

$$
=\left\{\left[\Delta \mathrm{H}_{\text {Treated }}-\Delta \mathrm{H}_{\text {Control }}\right] / \Delta \mathrm{H}_{\text {Control }}\right\} \times 100
$$

Where $\Delta \mathrm{H}_{\text {Control }}$ and $\Delta \mathrm{H}_{\text {Treated }}$ are the latent heat of fusion of the control and treated selenium, respectively.

\section{Thermal gravimetric analysis (TGA)/ Differential thermo- gravimetric analysis (DTG)}

TGA/DTG thermograms of seleniumwere obtained with the help of TGA Q50TA instruments. A sample of $5 \mathrm{mg}$ was loaded to the platinum crucible at a heating rate of $10^{\circ} \mathrm{C} / \mathrm{min}$ from $25^{\circ} \mathrm{C}$ to $1000{ }^{\circ} \mathrm{C}$ with the recent literature ${ }^{[34,35]}$. The $\%$ change in weight loss (W) was calculated using the following equation 7 :

$\%$ change in weight loss $=\left\{\left[\mathrm{W}_{\text {Treated }}-\mathrm{W}_{\text {Control }}\right] / \mathrm{W}_{\text {Control }}\right\} \times 100$

Where $\mathrm{W}_{\text {Control }}$ and $\mathrm{W}_{\text {Treated }}$ are the weight loss of the control and the Biofield Energy Treated selenium, respectively.

The $\%$ change in maximum thermal degradation temperature $\left(\mathrm{T}_{\max }\right)(\mathrm{M})$ was calculated using the following equation 8:

$\%$ change in $\mathrm{T}_{\max }(\mathrm{M})=\left\{\left[\mathrm{M}_{\text {Treated }}-\mathrm{M}_{\text {Control }}\right] / \mathrm{M}_{\text {Control }}\right\} \times 100$

Where $\mathrm{M}_{\text {Control }}$ and $\mathrm{M}_{\text {Treated }}$ are the $\mathrm{T}_{\max }$ values of the control and the Biofield Energy Treated selenium, respectively.

\section{Results and Discussion}

\section{Powder X-ray diffraction (PXRD) analysis}

The PXRD diffractograms of the control and the Biofield Energy Treated selenium showed sharp and intense peaks, which indicated that both the samples were crystalline in nature. The PXRD diffractograms of the control and the Biofield Energy Treated samples showed the highest peak intensity at $2 \theta$ equal to $29.7^{\circ} \mathrm{C}$ (Table 1, entry 2). The peak intensities of the Biofield Energy Treated sample were altered ranging from $-21.59 \%$ to $412.20 \%$ compared with the control sample. Similarly, the crystallite sizes of the treated sample were significantly altered ranging from $-6.90 \%$ to $40.68 \%$ compared to the control sample. Overall, the average crystallite size of the Biofield Energy Treated selenium $(94.71 \mathrm{~nm})$ was significantly increased by $5.44 \%$ compared with the control sample $(89.82 \mathrm{~nm})$.
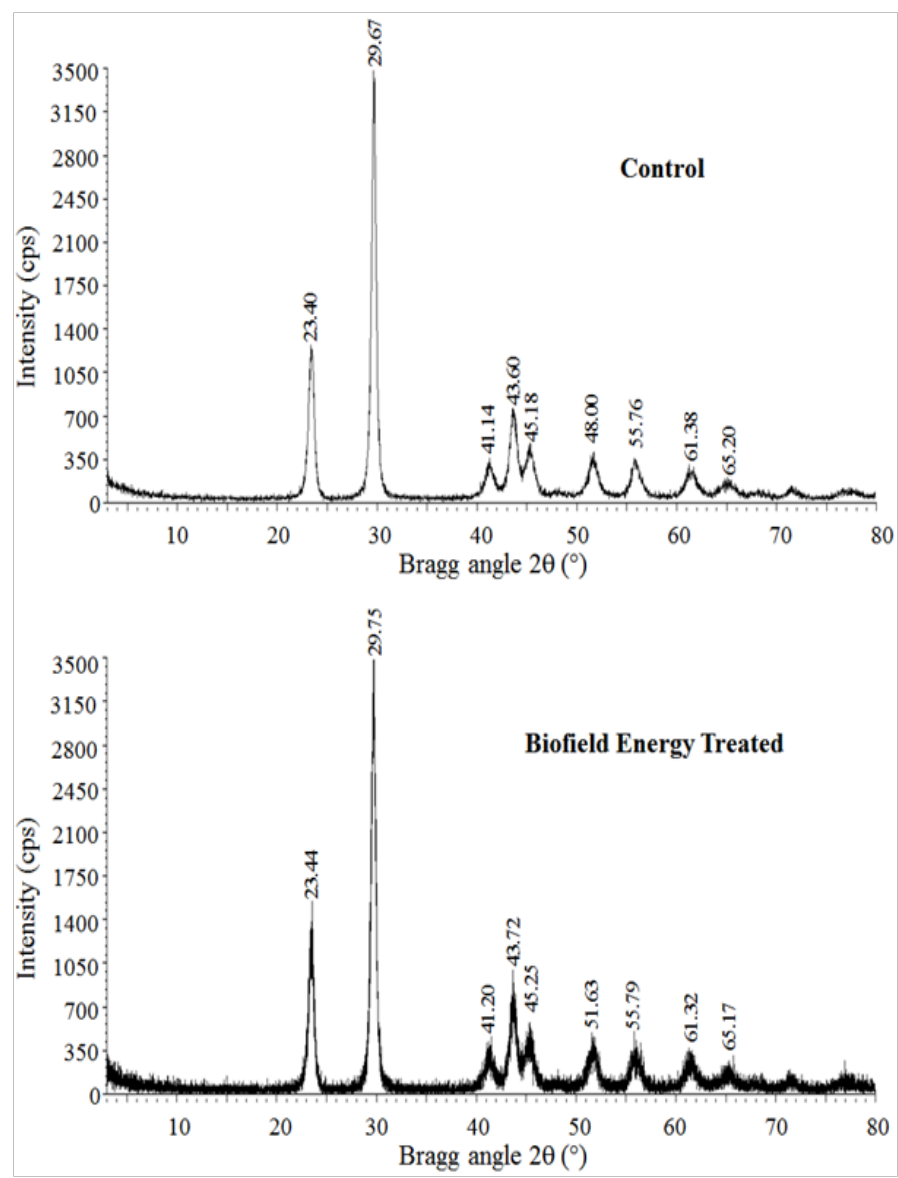

Figure 1: PXRD diffractograms of the control and the Biofield Energy Treated sample.

Table 1: PXRD data for the control and the Biofield Energy Treated selenium.

\begin{tabular}{|c|c|c|c|c|c|c|c|c|}
\hline \multirow{2}{*}{$\begin{array}{l}\text { En- } \\
\text { try } \\
\text { No. }\end{array}$} & \multicolumn{2}{|c|}{$\begin{array}{l}\text { Bragg angle } \\
\left({ }^{\circ} 2 \theta\right)\end{array}$} & \multicolumn{3}{|c|}{ Peak Intensity (\%) } & \multicolumn{3}{|c|}{ Crystallite size $(\mathrm{G}, \mathrm{nm})$} \\
\hline & $\begin{array}{l}\text { Con - } \\
\text { trol }\end{array}$ & $\begin{array}{l}\text { Tre- } \\
\text { ated }\end{array}$ & $\begin{array}{l}\text { Con- } \\
\text { trol }\end{array}$ & $\begin{array}{l}\text { Tre- } \\
\text { ated }\end{array}$ & $\begin{array}{l}\% \text { cha } \\
\text { nge }^{\text {a }}\end{array}$ & $\begin{array}{l}\text { Con- } \\
\text { trol }\end{array}$ & $\begin{array}{l}\text { Treat- } \\
\text { ed }\end{array}$ & $\begin{array}{l}\% \text { cha } \\
\text { nge }^{b}\end{array}$ \\
\hline 1 & 23.40 & 23.44 & 645 & 577 & -10.54 & 122.70 & 120.50 & -1.79 \\
\hline 2 & 29.67 & 29.75 & 1489 & 1378 & -7.45 & 154.70 & 146.90 & -5.04 \\
\hline 3 & 41.14 & 41.20 & 187 & 173 & -7.49 & 78.00 & 77.00 & -1.28 \\
\hline 4 & 43.60 & 43.72 & 440 & 384 & -12.73 & 98.00 & 103.00 & 5.10 \\
\hline 5 & 45.18 & 45.25 & 314 & 281 & -10.51 & 76.00 & 75.00 & -1.32 \\
\hline 6 & 48.00 & 51.63 & 41 & 210 & 412.20 & 59.00 & 83.00 & 40.68 \\
\hline 7 & 55.76 & 55.79 & 181 & 189 & 4.42 & 87.00 & 81.00 & -6.90 \\
\hline 8 & 61.38 & 61.32 & 173 & 149 & -13.87 & 68.00 & 89.00 & 30.88 \\
\hline 9 & 65.20 & 65.17 & 88 & 69 & -21.59 & 65.00 & 77.00 & 18.46 \\
\hline 10 & \multicolumn{5}{|c|}{ Average crystallite size } & 89.82 & 94.71 & 5.44 \\
\hline
\end{tabular}

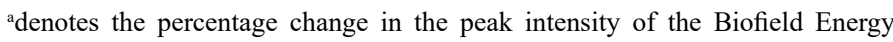

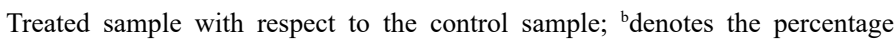
change in the crystallite size of the Biofield Energy Treated sample with respect to the control sample.

The variations in the crystallite sizes and peak intensities indicated the modification of the crystal morphology of the Biofield Energy Treated selenium compared to the control sample. The peak intensity of each diffraction face on the crystalline compound changes according to the crystal morpholo- 
gy $^{[36]}$ and alterations in the PXRD pattern provide the proof of polymorphic transitions ${ }^{[37,38]}$. The Trivedi Effect ${ }^{\mathbb{}}$-Consciousness Energy Healing Treatment probably produced the new polymorphic form of selenium through the Biofield Energy via neutri$\operatorname{nos}^{[12]}$. Different polymorphic forms of pharmaceuticals have the significant effects on drug performance, such as bioavailability, therapeutic efficacy, and toxicity, because of their thermodynamic and physicochemical properties like melting point, energy, stability, and especially solubility, are different (probably an improvement) from the original form ${ }^{[39,40]}$. Thus, it can be anticipated that the Trivedi Effect ${ }^{\circledR}$ Treated selenium would be better in designing pharmaceutical and nutraceutical formulations containing selenium.

\section{Particle size analysis (PSA)}

The particle size distribution analysis of both the control and the Biofield Energy Treated selenium was performed, and the data are presented in Table 2. The particle size values of the control selenium at $d_{10}, d_{50}, d_{90}$, and $\mathrm{D}(4,3)$ were $9.913 \mu \mathrm{m}, 26.033 \mu \mathrm{m}$, $52.445 \mu \mathrm{m}$, and $28.933 \mu \mathrm{m}$, respectively. Similarly, the particle sizes of the Biofield Energy Treated selenium at $\mathrm{d}_{10}, \mathrm{~d}_{50}, \mathrm{~d}_{90}$, and $\mathrm{D}(4,3)$ were $9.464 \mu \mathrm{m}, 26.267 \mu \mathrm{m}, 53.075 \mu \mathrm{m}$, and 29.119 $\mu \mathrm{m}$ respectively. Therefore, the particle size values in Alice's Biofield Energy Treated selenium were decreased by $4.54 \%$ at $\mathrm{d}_{10}$ and increased by $0.92 \%, 1.18 \%$, and $0.66 \%$ at $\mathrm{d}_{50}, \mathrm{~d}_{90}$, and $\mathrm{D}(4,3)$, respectively compared to the control sample. The specific surface area of the Biofield Energy Treated selenium $(0.331$ $\mathrm{m}^{2} / \mathrm{g}$ ) was increased by $2.48 \%$ compared with the control sample $\left(0.323 \mathrm{~m}^{2} / \mathrm{g}\right)$. Hence, it can be assumed that the Trivedi Effect $^{\circledR}$-Consciousness Energy Healing Treatment might act as an external force for reducing the particle size of selenium. Many kinds of literature reported that pharmaceutical compounds on reducing the particle size increase the surface area and improve the solubility, dissolution rate, and bioavailability in the physiological system ${ }^{[11,41]}$. Thus, it is anticipated that the Trivedi Effect ${ }^{\circledR}$ Treated selenium might offer better bioavailability compared with the untreated sample.

Table 2: Particle size distribution of the control and the Biofield Energy Treated selenium

\begin{tabular}{|l|l|l|l|l|l|}
\hline Parameter & $\mathrm{d}_{10}(\mu \mathrm{m})$ & $\mathrm{d}_{50}(\mu \mathrm{m})$ & $\mathrm{d}_{90}(\mu \mathrm{m})$ & $\mathrm{D}(4,3)(\mu \mathrm{m})$ & $\mathrm{SSA}\left(\mathrm{m}^{2} / \mathrm{g}\right)$ \\
\hline Control & 9.913 & 26.033 & 52.445 & 28.933 & 0.323 \\
\hline $\begin{array}{l}\text { Biofield } \\
\text { Treated }\end{array}$ & 9.464 & 26.267 & 53.075 & 29.119 & 0.331 \\
\hline $\begin{array}{l}\text { Percent } \\
\text { change* } \\
(\%)\end{array}$ & -4.54 & 0.92 & 1.18 & 0.66 & 2.48 \\
\hline
\end{tabular}

$\mathrm{d}_{10}, \mathrm{~d}_{50}$, and $\mathrm{d}_{90}$ : particle diameter corresponding to $10 \%, 50 \%$, and $90 \%$ of the cumulative distribution, $\mathrm{D}(4,3)$ : the average mass-volume diameter, and SSA: the specific surface area. *denotes the \% change in the Particle size distribution of the Biofield Energy Treated sample with respect to the control sample.

\section{Differential scanning calorimetry (DSC) analysis}

DSC analysis has been performed to characterize the thermal behavior of both control and the Biofield Energy Treated selenium (Table 3 and Figure 2). The DSC thermograms of the control and the Biofield Energy Treated selenium showed sharp endo- thermic peaks at 221.38 and $221.97^{\circ} \mathrm{C}$, respectively (Figure 2). The melting point of the Biofield Energy Treated selenium was slightly increased by $0.27 \%$ compared with the control sample(Table 3).

Table 3: DSC data for both control and the Biofield Energy Treated samples of selenium

\begin{tabular}{|l|l|l|}
\hline Sample & Melting point $\left({ }^{\circ} \mathbf{C}\right)$ & $\Delta \mathbf{H}(\mathbf{J} / \mathbf{g})$ \\
\hline Control Sample & 221.38 & 73.12 \\
\hline Biofield Energy Treated & 221.97 & 77.46 \\
\hline \% Change* & 0.27 & 5.94 \\
\hline
\end{tabular}
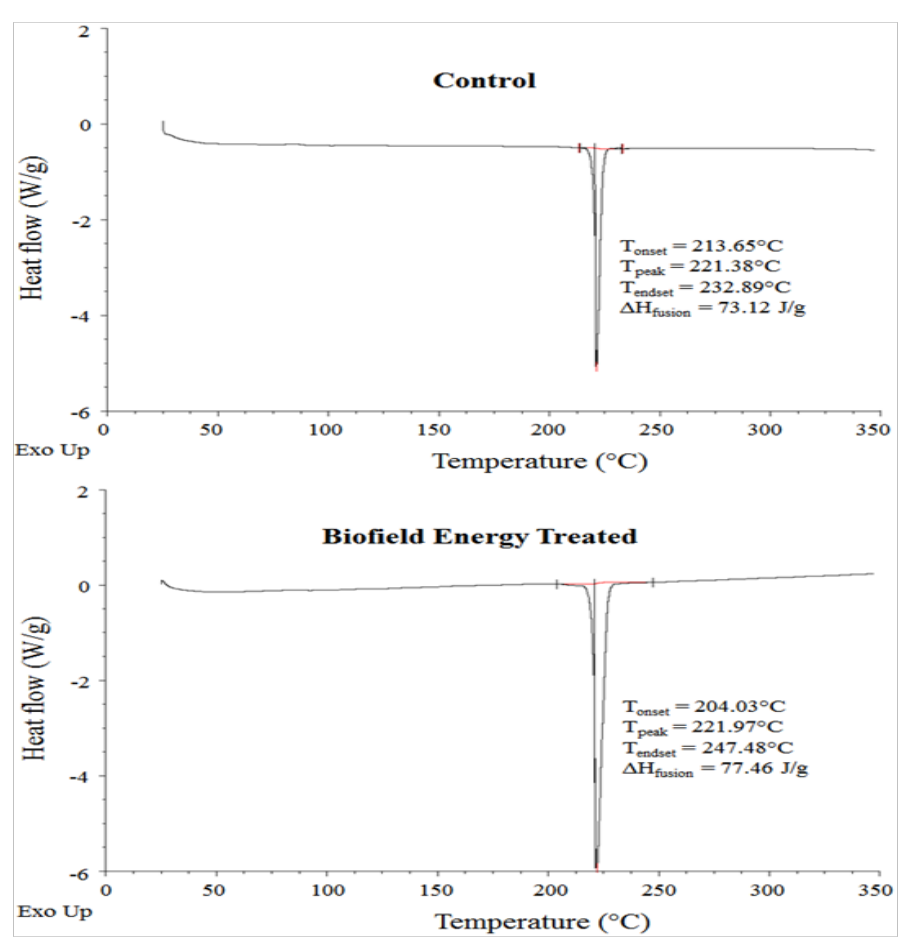

Figure 2: DSC thermograms of the control and the Biofield Energy Treated selenium

$\Delta \mathrm{H}$ : Latent heat of fusion, ${ }^{*}$ denotes the percentage change of the Biofield Energy Treated sample w.r.t. the control sample.

The latent heat of fusion $\left(\Delta \mathrm{H}_{\text {fusion }}\right)$ of the Biofield Energy Treated selenium $(77.46 \mathrm{~J} / \mathrm{g})$ was significantly increased by $5.94 \%$ compared with the control sample $(73.12 \mathrm{~J} / \mathrm{g}$ ) (Table 3$)$. The change in the latent heat of fusion can be attributed to the disrupted molecule chains and any change in the crystal structure $^{[41]}$. Thus, it can be assumed that Alice Branton's Biofield Energy Treatment might be responsible for the disruption the molecular chains and crystal structure of selenium which was the cause of improved thermal stability of the treated sample compared with the control sample.

\section{Thermal gravimetric analysis (TGA) / Differential thermo- gravimetric analysis (DTG)}

The TGA thermograms of the control and the Biofield Energy Treated samples displayed one step of thermal degradation (Figure 3). The total weight loss in the Biofield Energy Treated selenium was decreased by $0.07 \%$ compared with the control sample (Table 4). Therefore, the residue amount was increased 
Citation: Branton, A., et al. Effect of Consciousness Energy Healing Treatment on the Physicochemical and Thermal Properties of Selenium. (2018) Int J Food Nutr Sci 5(1): 74- 80.

by $3.83 \%$ in the Biofield Energy Treated selenium compared to the control sample (Table 4).

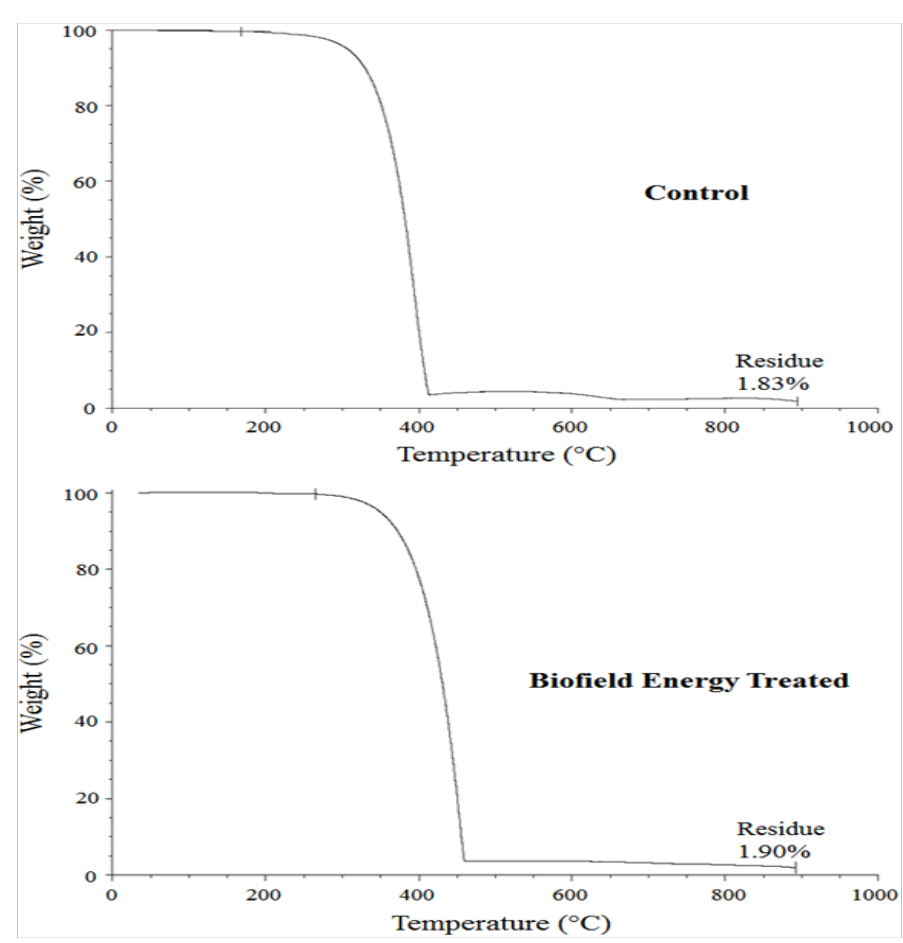

Figure 3: TGA thermograms of the control and the Biofield Energy Treatedselenium

The DTG thermograms of the control and the Biofield Energy Treated selenium has shown only one peak (Figure 4). The control selenium was thermally stable up to $393.79{ }^{\circ} \mathrm{C}$, while the Biofield Energy Treated selenium was stable up to 452.62 ${ }^{\circ} \mathrm{C}$. The $\mathrm{T}_{\max }$ of the treated sample was significantly increased by $14.94 \%$ compared to the control sample (Table 4 ). Overall, TGA/DTG revealed that the thermal stability of the Biofield Energy Treated selenium was significantly improved compared with the control sample.

Table 4: TGA/DTG data of the control and the Biofield Energy Treated samples of selenium

\begin{tabular}{|l|c|c|c|}
\hline \multirow{2}{*}{ Sample } & \multicolumn{2}{|l|}{ TGA } & DTG \\
\cline { 2 - 4 } & Total weight loss (\%) & Residue \% & $\mathbf{T}_{\max }\left({ }^{\circ} \mathbf{C}\right)$ \\
\hline Control & 98.17 & 1.83 & 393.79 \\
\hline $\begin{array}{l}\text { Biofield Energy } \\
\text { Treated }\end{array}$ & 98.10 & 1.90 & 452.62 \\
\hline \% Change* & -0.07 & 3.83 & 14.94 \\
\hline
\end{tabular}

*denotes the percentage change of the Biofield Energy Treated sample with respect to the control sample,

$\mathrm{T}_{\max }=$ the temperature at which maximum weight loss takes place in TG or peak temperature in DTG.
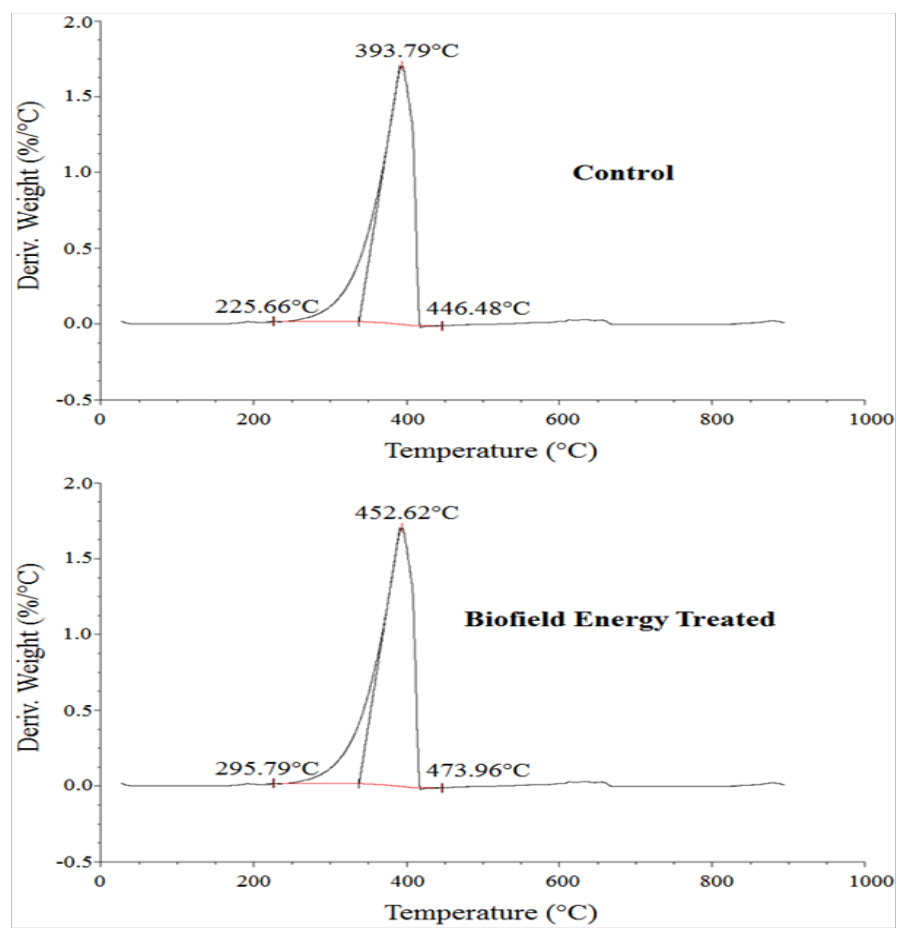

Figure 4: DTG thermograms of the control and the Biofield Energy Treated selenium

\section{Conclusion}

The Trivedi Effect ${ }^{\circledR}$-Consciousness Energy Healing Treatment has shown significant effects on the peak intensities, crystallite size, particle size, surface area, and thermal properties of selenium. The PXRD data indicating that the peak intensities of the Alice's Biofield Energy Treated selenium were altered from -21.59 to $412.20 \%$ compared with the control sample. Similarly, the crystallite sizes of the Biofield Energy Treated sample were significantly altered ranging from $-6.90 \%$ to $40.68 \%$ compared to the control sample. However, the average crystallite size of the Biofield Energy Treated sample was significantly increased by $5.44 \%$ compared with the control sample. The particle size values of the Biofield Energy Treated selenium were decreased at $\mathrm{d}_{10}$ by $4.54 \%$ and increased at $\mathrm{d}_{50}, \mathrm{~d}_{90}$, and $\mathrm{D}(4,3)$ by $0.92 \%$, $1.18 \%$, and $0.66 \%$, respectively compared to the control sample. The specific surface area of Biofield Energy Treated selenium was increased by $2.48 \%$ in contrast with the control sample. The DSC results revealed that the melting point and $\Delta \mathrm{H}_{\text {fusion }}$ of the Biofield Energy Treated selenium was increased by $0.27 \%$ and $5.94 \%$, respectively compared with the control sample. The total weight loss was decreased by $0.07 \%$; therefore the residue amount was increased by $3.83 \%$ in the Biofield Energy Treated selenium compared with the control sample. The $\mathrm{T}_{\max }$ of the Biofield Energy Treated sample was significantly increased by $14.94 \%$ compared with the control sample. The Trivedi Effect ${ }^{\circledR}$-Consciousness Energy Healing Treatment might lead to generate a new polymorphic form of selenium which would be more soluble, bioavailable, and be thermally stable compared with the untreated sample. The Biofield Energy Treated selenium would be more efficacious in nutraceutical and pharmaceutical formulations that might offer better therapeutic responses against type- 2 diabetes, cancer, cardiovascular disease, viral diseases, male infertility, stress, aging, muscle disorders, neurolog- 
ical disorders, degenerative ailments, etc.

Acknowledgements: The authors are grateful to Central Leather Research Institute, SIPRA Lab. Ltd., Trivedi Science, Trivedi Global, Inc., Trivedi Testimonials, and Trivedi Master Wellness for their assistance and support during this work.

Conflict of Interest: Authors declare no conflict of interest.

\section{References}

1. Dietary Supplement Fact Sheet: Selenium. National Institutes of Health; Office of Dietary Supplements. Pubmed | Crossref $\mid$ Others

2. Margaret, N.I., Allan, M.P., James, D. Selenium content of a range of UK food. (1995) J Food Compos Anal 8(4): 307318.

Pubmed | Crossref | Others

3. Stadtman, T.C. Selenocysteine. (1996) Annu Rev Biochem 65: $83-100$

Pubmed | Crossref | Others

4. Li, X., Yin, D., Yin, J., et al. Dietary selenium protect against redox-mediated immune suppression induced by methylmercury exposure. (2014) Food Chem Toxicol 72: 169-177.

Pubmed | Crossref | Others

5. Yang, X., Bao, Y., Fu, H., et al. Selenium protects neonates against neurotoxicity from prenatal exposure to manganese. (2014) PloS one 9: e86611.

Pubmed | Crossref | Others

6. Rayman, M.P. Selenium and human health. (2012) The Lancet 379(9822): 1256-1268.

Pubmed | Crossref | Others

7. Hatfield, D.L., Tsuji, P.A., Carlson, B.A., et al. Selenium and selenocysteine: roles in cancer, health, and development. (2014) Trends Biochem Sci 39(3): 112-120. Pubmed | Crossref | Others

8. Roman, M., Jitaru, P., Barbante, C. Selenium biochemistry and its role for human health. (2014) Metallomics 6(1): 2554.

Pubmed | Crossref | Others

9. Brenneisen, P., Steinbrenner, H., Sies, H. Selenium, oxidative stress, health aspects. (2005) Mol Aspects Med 26(4-5): 256-267.

Pubmed | Crossref | Others

10. Levander OA, Burk RF Update of human dietary standards for selenium. In: Hatfield DL, Berry MJ, Gladyshev VN, (Eds) Selenium - its molecular biology and role in human health, Springer, (2006) New York.

Pubmed | Crossref $\mid$ Others

11. Chereson, R. Bioavailability, bioequivalence, and drug selection. In: Makoid CM, Vuchetich PJ, Banakar UV (Eds) Basic pharmacokinetics (2009) (1 ${ }^{\text {st }}$ Edn) Pharmaceutical Press, London.

Pubmed | Crossref | Others

12. Trivedi, M.K., Mohan, T.R. Biofield energy signals, energy transmission and neutrinos. (2016) American Journal of Modern Physics 5(6): 172-176.

Pubmed | Crossref | Others
13. Trivedi, M.K., Branton, A., Trivedi, D., et al. Impact of biofield energy treated herbomineral formulation (the Trivedi Effect ${ }^{\mathbb{B}}$ ) on mouse dendritic and splenocyte cells for modulation of pro-inflammatory cytokines. (2016) Inter J Immunol 4: 35-45.

Pubmed | Crossref $\mid$ Others

14. Trivedi, M.K., Branton, A., Trivedi, D., et al. Effect of the energy of consciousness (the Trivedi Effect ${ }^{\circledR}$ ) on the structural properties and isotopic abundance ratio of magnesium gluconate using LC-MS and NMR spectroscopy. (2017) Advances in Biochemistry 5: 7-15.

Pubmed | Crossref | Others

15. Trivedi, M.K., Branton, A., Trivedi, D., et al. An Impact of energy of consciousness (the Trivedi Effect ${ }^{\circledR}$ ) on the physicochemical, thermal, structural, and behavioral properties of magnesium gluconate. (2017) Biomedical Sciences 3: 42-54.

Pubmed | Crossref | Others

16. Rubik, B., Muehsam, D., Hammerschlag, R., et al. Biofield science and healing: history, terminology, and concepts. (2015) Glob Adv Health Med 4: 8-14.

Pubmed | Crossref | Others

17. Barnes, P.M., Bloom, B., Nahin, R.L. Complementary and alternative medicine use among adults and children: United States, 2007. (2008) Natl Health Stat Report 12: 1-23. Pubmed $\mid$ Crossref $\mid$ Others

18. Koithan, M. Introducing complementary and alternative therapies. (2009) J Nurse Pract 5: 18-20.

Pubmed | Crossref | Others

19. Trivedi, M.K., Tallapragada, R.M., Branton, A., et al. (2015) Characterization of physical and structural properties of aluminum carbide powder: Impact of biofield treatment. J Aeronaut Aerospace Eng 4: 142.

Pubmed | Crossref | Others

20. Trivedi, M.K., Patil, S., Tallapragada, R.M. Effect of biofield treatment on the physical and thermal characteristics of vanadium pentoxide powders. (2013) J Material Sci Eng 11: 001 .

Pubmed $\mid$ Crossref $\mid$ Others

21. Trivedi, M.K., Branton, A., Trivedi, D., et al. (2016) Gas chromatography-mass spectrometry based isotopic abundance ratio analysis of biofield energy treated methyl2-napthylether (Nerolin). American Journal of Physical Chemistry 5: 80-86.

Pubmed | Crossref | Others

22. Trivedi, M.K., Branton, A., Trivedi, D., et al. Spectroscopic characterization of disodium hydrogen orthophosphate and sodium nitrate after biofield treatment. (2015) J Chromatogr Sep Tech 6: 282.

Pubmed $\mid$ Crossref $\mid$ Others

23. Trivedi, M.K., Branton, A., Trivedi, D., et al. Evaluation of the isotopic abundance ratio in biofield energy treated resorcinol using gas chromatography-mass spectrometry technique. (2016) Pharm Anal Acta 7: 481.

Pubmed | Crossref $\mid$ Others

24. Trivedi, M.K., Tallapragada, R.M., Branton, A., et al. Potential impact of biofield treatment on atomic and physical characteristics of magnesium. (2015) Vitam Miner 3: 129. Pubmed | Crossref | Others 
Citation: Branton, A., et al. Effect of Consciousness Energy Healing Treatment on the Physicochemical and Thermal Properties of Selenium. (2018) Int J Food Nutr Sci 5(1): 74- 80.

25. Trivedi, M.K., Patil, S., Shettigar, H., et al. Effect of biofield treatment on spectral properties of paracetamol and piroxicam. (2015) Chem Sci J 6: 98. Pubmed | Crossref $\mid$ Others

26. Trivedi, M.K., Branton, A., Trivedi, D., et al. Agronomic characteristics, growth analysis, and yield response of biofield treated mustard, cowpea, horse gram, and groundnuts. (2015) International Journal of Genetics and Genomics. 3: 74-80.

Pubmed $\mid$ Crossref $\mid$ Others

27. Trivedi, M.K., Branton, A., Trivedi, D., et al. Evaluation of plant growth, yield and yield attributes of biofield energy treated mustard (brassica juncea) and chick pea (Cicer arietinum) seeds. (2015) Agriculture, Forestry and Fisheries. 4: 291-295.

Pubmed $\mid$ Crossref $\mid$ Others

28. Branton, A., Jana, S. Effect of The biofield energy healing treatment on the pharmacokinetics of 25-hydroxyvitamin $\mathrm{D}_{3}\left[25(\mathrm{OH}) \mathrm{D}_{3}\right]$ in rats after a single oral dose of vitamin $\mathrm{D}_{3}$. (2017) American Journal of Pharmacology and Phytotherapy 2(1): 11-18.

Pubmed $\mid$ Crossref $\mid$ Others

29. Branton, A., Jana, S. The influence of energy of consciousness healing treatment on low bioavailable resveratrol in male Sprague Dawley rats. (2017) International Journal of Clinical and Developmental Anatomy 3: 9-15.

Pubmed | Crossref $\mid$ Others

30. Branton, A., Jana, S. The use of novel and unique biofield energy healing treatment for the improvement of poorly bioavailable compound, berberine in male Sprague Dawley rats. (2017) American Journal of Clinical and Experimental Medicine 5(4): 138-144.

Pubmed | Crossref $\mid$ Others

31. Desktop X-ray Diffractometer "MiniFlex+". (1997) The Rigaku Journal 14: 29-36.

Pubmed $\mid$ Crossref $\mid$ Others

32. Zhang, T., Paluch, K., Scalabrino, G., et al. (2015) Molecular structure studies of (1S,2S)-2-benzyl-2,3-dihydro-2(1Hinden-2-yl)-1H-inden-1-ol. J Mol Struct 1083: 286-299. Pubmed | Crossref | Others

33. Langford, J.I., Wilson, A.J. Scherrer after sixty years: A survey and some new results in the determination of crystallite size. (1978) J Appl Cryst 11: 102-113.

Pubmed $\mid$ Crossref $\mid$ Others

34. Trivedi, M.K., Sethi, K.K., Panda, P., et al. (2017) A comprehensive physicochemical, thermal, and spectroscopic characterization of zinc (II) chloride using X-ray diffraction, particle size distribution, differential scanning calorimetry, thermogravimetric analysis/differential thermogravimetric analysis, ultraviolet-visible, and Fourier transform-infrared spectroscopy. Int J Pharm Investig 7(1): 33-40.

Pubmed | Crossref | Others

35. Trivedi, M.K., Sethi, K.K., Panda, P., et al. Physicochemical, thermal and spectroscopic characterization of sodium selenate using XRD, PSD, DSC, TGA/DTG, UV-vis, and FT-IR. (2017) Marmara Pharmaceutical Journal 21/2: 311318.

Pubmed $\mid$ Crossref $\mid$ Others

36. Inoue, M., Hirasawa, I. The relationship between crystal morphology and XRD peak intensity on $\mathrm{CaSO}_{4} \cdot 2 \mathrm{H}_{2} \mathrm{O}$. (2013) J Crystal Growth 380: 169-175.

Pubmed $\mid$ Crossref $\mid$ Others

37. Raza, K., Kumar, P., Ratan, S., et al (2014) Polymorphism: The phenomenon affecting the performance of drugs. SOJ Pharm Pharm Sci 1: 10.

Pubmed $\mid$ Crossref $\mid$ Others

38. Brittain, H.G. Polymorphism in pharmaceutical solids in Drugs and Pharmaceutical Sciences, volume 192, $2^{\text {nd }}$ Edn, (2009) Informa Healthcare USA, Inc., New York.

Pubmed | Crossref $\mid$ Others

39. Censi, R., Martino, P.D. Polymorph Impact on the Bioavailability and Stability of Poorly Soluble Drugs. (2015) Molecules 20: 18759-18776.

Pubmed | Crossref | Others

40. Blagden, N., de Matas, M., Gavan, P.T., et al. Crystal engineering of active pharmaceutical ingredients to improve solubility and dissolution rates. (2007) Adv Drug Deliv Rev 59(7): 617-630.

Pubmed | Crossref | Others

41. Zhao, Z, Xie, M., Li, Y., et al. Formation of curcumin nanoparticles via solution-enhanced dispersion by supercritical $\mathrm{CO}_{2}$. (2015) Int J Nanomedicine 10: 31713181.

Pubmed | Crossref | Others

Submit your manuscript to Ommega Publishers and we will help you at every step:

- We accept pre-submission inquiries

- Our selector tool helps you to find the most relevant journal

- We provide round the clock customer support

- Convenient online submission

- Thorough peer review

- Inclusion in all major indexing services

- Maximum visibility for your research

Submit your manuscript at OMmEga Publishers https://www.ommegaonline.org/submit-manuscript 